\title{
Supervision System for the Management of Regional Revenue and Expenditure Budgets in Makassar City
}

\author{
Ernita Rahmadhani Bym ${ }^{1 *}$, Andi Pangerang Moenta ${ }^{1}$, Zulkifli Aspan ${ }^{1}$ \\ 1 Faculty of Law, Hasanuddin University, Indonesia \\ *Correspondence: Rahmadhanibymernita@gmail.com
}

\section{ARTICLE HISTORY}

Received: 03.09.2021

Accepted: 24.12.2021

Published: 27.12.2021

\section{ARTICLE LICENCE}

Copyright (C) 2021 The Author(s): This is an

open-access article distributed under the terms of the Creative Commons Attribution

ShareAlike 4.0

International (CC BY-SA 4.0)

\begin{abstract}
This study aims to analyze the system and mechanism of supervision of the management of the $A P B D$ and the form of implementation of the supervision of the management of the APBD in Makassar City. This research was conducted using empirical normative research methods. The data collection technique used is in the form of field research by interviewing related parties and conducting library research. The results showed that the supervision carried out by the DPRD and the Makassar City Inspectorate had not run optimally due to the many shortcomings in the supervision process. The form of implementation of supervision has been carried out well, however, there were many problems found because there were several individuals who made administrative errors such as delays in providing data.
\end{abstract}

Keywords: APBD; Makassar City; Supervision

\section{Introduction}

Anggaran Pendapatan Belanja or APBD is a technique for managing regional financial resources. Regional financial management is meant to ensure the formation of an orderly, predictable, and just environment (Hamidi, 2012). With regional financial management in place, it is believed that management will be more orderly and effective in motivating economic improvement, budget distribution that is on target, and the creation of more stable economic conditions for the community's welfare (Madura, 2001).

Management of an APBD encompasses all activities, including planning, budgeting, implementation, administration, reporting, accountability, and monitoring (Mardiasmo, 2002). The APBD's management requires oversight to ensure that the government's objectives are met. Where budget control is conducted to verify that the APBD is managed in accordance with its objectives and strategies. APBD oversight acts as a reference for selecting and evaluating the appropriateness of budget implementation, including whether the budget to be utilized complies with applicable regulations (Fahmil, 2008).

Supervision of the APBD is critical to ensuring that there are no leakages or anomalies in APBD earnings and expenditures and to achieving good governance, namely responsible governance (Syauqi et al., 2017). The strategy for supervising local government implementation is expected to avoid corruption, collusion, nepotism, abuse of authority, leakage, waste of state wealth and authority, illegal levies, and a variety of other types of anomalies that can obstruct development implementation (Nawawi, 2019).

According to SuaraSulsel.id, the Makassar City Regional House of Representatives (DPRD) has urged the Makassar City Government to bravely release data on the Covid-19 handling budget. This is because hundreds of billions of rupiah were discovered in the Covid-19 budget that were not recognized (Yunus, 2020). These findings imply that good governance has not been effectively implemented in Makassar City. 


\section{Methodology}

The author employs two distinct types of research in this study: empirical and normative. Empirical study is field research that examines the law in its natural setting and how it operates in the community. Additionally, normative research is utilized to supplement empirical research in order to ascertain the rule of law in order to resolve existing legal challenges. The re search was conducted at Makassar City's Regional Financial and Asset Management Agency (BPKAD), Makassar City DPRD, and Makassar City Inspectorate. Direct observation is used to collect data, as well as documentation and interviews with relevant sources, as well as a review of the literature. After collecting data from field research and the literature, it is processed to create systematic data.

\section{Result and Discussion}

To make it real Good governance namely a system of government with good and accountable governance requires internal and external supervision (Pradana, 2014). Internal supervision is carried out by a supervisory unit which is under the scope of the government, namely the temporary inspectorate, while the external supervisory function, outside the scope of the Makassar city government, is carried out by the DPRD. This is in line with the mandate of Article 218 of Law Number 23/2014 concerning the function of internal control, which includes the following: (1) The government is responsible for supervising the administration of regional government, which includes the following: a. Supervising the implementation of government affairs in the regions; and $\mathrm{b}$. Supervising regional regulations and regional head regulations. (2) In accordance with applicable laws and regulations, the supervision referred to in paragraph (1) letter an is carried out by the government's internal supervisory apparatus.

Concerning the DPRD's supervisory function, it is clearly defined in Article 153 of Law 23/2014, which includes the following: a. Implementation of district/city regulations and regent/mayor regulations; b. Implementation of other laws and regulations pertaining to the administration of district/city regional governments; and c. Implementation of follow-up on the results of the Supreme Audit Agency's audit of financial statements.

\subsection{Monitoring of APBD by DPRD Makassar City}

Supervision of APBD administration by DPRD is a right that each DPRD member has in the context of defending the community's interests. This oversight attempts to ensure that the government's budget for activities and development is implemented in a manner consistent with community expectations ('Amalia, 2013). As stated in Article 1 point 4 of Law 23/2014, DPRD is a regional people's representative institution that is domiciled as an element of regional government administration. DPRD is an external supervisor which one of its duties and authorities is to supervise.

The supervisory function of the Makassar City DPRD is regulated in Article 23 of Makassar City DPRD Regulation Number 2 of 2019 concerning Amendments to the Regulation of the Makas sar City Regional People's Representative Council Number 1 of 2018 concerning Orders as follows:

a) The supervisory function is carried out through the following: a) Supervision of the implementation of local regulations and mayoral regulations; $b$ ) Supervision of the implementation of other laws and regulations governing the administration of regional governments; and c) Supervision of the implementation of the results of the Audit Board's audit of financial statements.

b) The supervision referred to in paragraph (1) may be accomplished in the following ways: a) Commission work meetings with local governments; b) Working visits and field visits; c) General hearing meetings; and d) Community complaints.

c) Bapemperda performs the supervisory duty specified to in paragraph (1) letters a and b by conducting evaluations of the effectiveness of regional rules, mayoral regulations, and other laws and regulations.

Meanwhile, the duties and authorities are regulated in Law Number 9 of 2015 concerning the Second Amendment to Law Number 23 of 2014 concerning Regional Government Article 154. With the supervision of the APBD by the DPRD, it is hoped that the management of the APBD will run as expected. 
The supervision of the APBD by the DPRD is of course through a supervisory sys tem and of course it must follow the laws and regulations.

From the results of the interview by Mr. Hasanuddin Leo as a member of the DPRD, he explained the APBD supervision system by the DPRD as follows:

"Sebagaimana tri fungsi DPRD yang salah satunya adalah fungsi pengawasan terhadap APBD.
Sistem pengawasan oleh DPRD dimulai melakukan pembahasan dari apa yang telah direncanakan
oleh pemerintah kota, kemudian dibahas mulai dari pembahasan komisi-komisi dilanjutkan ke badan
anggaran, guna untuk melakukan semacam verifikasiterhadap apa yang menjadi perencanaan yang
telah dilakukan oleh pemerintah kota yang kemudian diajukan kepada DPRD.

Nah setelah dibahas dan dilakukan combine antara musrenbang dan hasil reses. Kemudian dilakukan pembahasan antara kami dan pemerintah kota apa yang menjadi kebutuhan masyarakat, apakah itu bisa tepenuhi dan bisa dianggarkan. Selanjutnya setelah itu disetujui maka akan dibahas per komisi baru ke badan anggaran dan selanjutnya diparpurnakan. Setelah diparipurnakan maka akan menjadi suatu dokumen dan akan diperdakan. Setelah dokumen di perdakan kemudian dijadikan pedoman dalam melihat apa yang menjadi pelaksanaan dilapangan."

"As for the three functions of the DPRD, one of which is the function of oversight of the APBD. The supervisory system by the DPRD begins with a discussion of what has been planned by the city government, then it is discussed starting from the discussion of the commissions proceed to the budget agency, in order to carry out a kind of verification of what is the plan that has been carried out by the city government which is then submitted to the DPRD.

Now, after discussing and combining the Musrenbang and the results of the recess. Then a discussion was held between us and the city government what the people's needs were, whether they could be met and budgeted for. Furthermore, after it is approved, it will be discussed per new commission to the budget agency and further refined. After it is finalized, it will become a document and will be traded. After the document is in the regional regulation, it is then used as a guide in seeing what is being implemented in the field."

The DPRD's monitoring is essentially a continual process that is more political in nature than technical. According to the author, based on the results of interviews, the process and supervisory mechanism used by the Makassar City DPRD have not operated properly, and the APBD monitoring process continues to have numerous flaws.

The existence of deficiencies in the supervision process that have not been addressed clearly violates the principles of good governance, efficiency, and effectiveness, which require that processes and institutions operate in accordance with established objectives and make optimal use of available resources. Where should the service performance go well and how well does it perform in comparison to expectations? This also occurred since there was no standard operating procedure for DPRD monitoring, and when the author questioned DPRD members, they simply stated that we followed the existing guidelines.

\subsection{Regional Budget Monitoring System by Makassar City Inspectorate}

The DPRD's monitoring is essentially a continual process that is more political in nature than technical. According to the author, based on the results of interviews, the process and supervisory mechanism used by the Makassar City DPRD have not operated properly, and the APBD monitoring process continues to have numerous flaws.

In carrying out the tasks referred to, the Makassar City Regional Inspectorate carries out the following functions: 1) Formulation of technical policies in the field of supervision and facilitation of supervision; 2) Implementation of internal control over performance and finances through audits, reviews, evaluations, monitoring, and other supervisory activities; 3 ) Implementation of supervision for certain purposes on the assignment of the Mayor; 4) Preparation of Monitoring Results Report; 5) Implementation of the administration of the Inspectorate; 6) Implementation of other functions given by the Mayor related to his duties and functions.

The Makassar City Regional Inspectorate has the following job descriptions to accomplish this task:

a. Development of a program for planning and functional oversight; 
b. Development of technical policies pertaining to functional oversight;

c. Oversight of local governmentadministration;

d. Conducting functional inspections of the regional apparatus and management of other Regional Owned Enterprises in the form of audits, reviews, evaluations, and monitoring, as well as other supervisory tasks;

e. Conducting public complaints and special examinations;

f. Conducting inquiries into alleged irregularities or abuses of authority based on examination results and public complaints;

g. Initiation of self-protective measures in response to alleged anomalies that could endanger the region;

h. Establishment of oversightand advisory mechanisms for the implementation of regional government;

i. Coordination of the planning, implementation, reporting, and follow-up on the results of the assessment of the Government's Internal and External Supervisory Apparatus (APIP and ESA);

j. Coordination of anti-corruption and anti-corruption efforts;

k. Work with the national governmentand local governments to coordinate bu reaucratic reform;

I. Provision of all parties with supervisory information services;

m. Planning and technical control of financial management, personnel management, and administration of regional property under their jurisdiction;

n. Implementation by the secretariatand;

o. Development of a functional workforce.F rom the job description above, we can see that the role of the inspectorate is to supervise as well as guide the budget that runs at every stage from planning to accountability.

From the results of interviews obtained from informant 2 who is an intermediate a uditor at the Makassar City Inspectorate explained that: "Mulai dari APBD yang ada di Kota, kami dari pihak inpsektorat sudah mengawal dari awal. Dari
awal sebelum jadi APBDkan ada turunnya, RPJMD, Renstra. Mulai ada Peraturan Menteri dalam
Negeri Nomor 13 Tahun 2006 tentang Pedoman Pengelolaan Keuangan Daerah, tugas inspektorat
mulai dariawal bukan hasapemeriksaan saja tapi kamijuga consulting pengawasan. Makanya mulai
dari awal sampai akhir, sebelum perencanaan disahkan kami sudah melakukan reviu apakah sudah
sesuai atau belum.

Dalam menyusun DPA ada standar satuan harga, analisis standar biaya dan lainnya kami reviu apakah sudah sesuai tidak dengan nilai-nilainya, sudah sesuaitidak dengan kententuan yang ada, efisienkah kemudian dibawa ke Anggota DPRD dibahas untuk disahkan, setalah itu dilaksanakan dan kami melakukan pemeriksaan setelah mereka belanjakan apakah sudah sesuai tidak dengan pelaksanaan $A P B D$.

Kami melakukan pengawasan mulai dari awal hingga akhir diawal itu namanya reviu sedangkan diakhir namanya audit regular. Jika ada masalah dalam pelaksanaannya kadang ada permintaan dari walikota atau dari mana kami melakukan audit khusus.

Kendala eksternal terkadang ada aspirasi anggaran yang tidak bisa diakomodir tetapi kebutuhan masyarakat sedangkan kendala internalnya mungkin lebih ke SDM yang kurang mengerti."

"Starting from the existing APBD in the City, we from the inspectorate have overseen it from the start. From the beginning, before becoming APBD, there was a decline, RPJMD, Strategic Plan. Starting with the Minister of Home Affairs Regulation Number 13 of 2006 concerning Guidelines for Regional Financial Management, the task of the inspectorate from the beginning is not only inspection but also consulting and supervision. That's why from the beginning to the end, before the planning was approved, we reviewed whether it was appropriate or not.

In preparing the DPA, there is a standard unit price, the analysis of cost standards and others, we review whether it is in accordance with the values, whether it is not in accordance with the existing provisions, is it efficient and then brought to DPRD members to be discussed for ratification, after 
that it is carried out and we conduct an inspection after they spend whether it is in accordance with the implementation of the APBD.

We carry out supervision from the beginning to the end, at the beginning it is called a review while at the end it is called a regular audit. If there is a problem in the implementation sometimes there is a request from the mayor or where we do a special audit.

External constraints sometimes include budget aspirations that cannot be accommodated but the needs of the community, while the internal constraints may be more to human resources who do not understand."

This was emphasized again by informant 3 who is a young auditor at the Makassar City Inspectorate that:

"Pengawasan yang dilakukan inspektorat yaitu Kami melakukan pengawasan dengan turun langsung ke obrik setelah diberikan surat tugas oleh pimpinan. Kami melakukan pemeriksaan mengenai beberapa transaksi pengguna anggaran SKPD apakah sudah sesuai aturan atau tidak.

Kami melakukan pengawasan langsung dengan terjun langsung kelapangan pemeriksaan dokumen dan jika ada hal-hal yang ingin di konfirmasikan secara langsung dengan pihak terkait maka kami lakukan konfirmasi pemeriksaan. Pada tahun 2020 kami melakukan pengawasan tidak langsung menggunakan aplikasi smart auditing.

Pengawasan preventifatau pencegahannya kami lakukanjasa konsultasi kepada SKPD -SKPD yang terkait agar tidak terjadipelanggaran, sedangkan represif jika ditemukan hal-hal yang menyimpang maka kami melakukan pemuktahiran data 2x setahun setiap 6 bulan. Seharusnya inspektorat diikutkan dalam perencanaan tapi selama ini kami melakukan reviu setelah ada laporan dari walikota".

"Supervision carried out by the inspectorate is that we carry out supervision by going directly to the office after being given a letter of assignment by the leadership. We conducted an examination of several transactions of SKPD budget users whether they were in accordance with the rules or not.

We carry out direct supervision by going directly to the field of document inspection and if there are things that we want to confirm directly with the related parties, we will confirm the inspection. In 2020 we conducted indirect supervision using the smart auditing application.

We provide preventive or preventive monitoring services to the related SKPD -SKPD so that violations do not occur, while repressively if things are found to be deviant, we update the data $2 x$ a year every 6 months. The inspectorate should have been included in the planning but so far we have been conducting a review after receiving a report from the mayor".

As we see the results of the interviews above, the authors conclude that the inspectorate officials have tried their best in supervising the budget, however, this is not optimal because there are several SKPD elements who do not comply with existing procedures such as being slow to collect data when it should be ready when the data is collected. requested by the inspectorate.

In the 2020 Makassar City Inspectorate Government Agency Performance Report (LKjIP), it is written that the problems faced by the Makassar City Regional Inspectorate are:

a. Human Resources (HR) in the field of supervision have not fully attended training and education for the certification of Functional Auditor Position (JFA), Government Supervisory Functional Position (P2UPD), and Personnel Auditor (Audiwan).

b. The limited number and qualifications of the apparatus' resources compared to the size of the object of examination.

c. Limited resources of qualified personnel with functional technical education.

d. Legislation that supports the enforcement and development of organizations that are always changing and evolving so that they cannot be accessed quickly and are not available in the Inspectorate library. 


\title{
3.3 Forms of Implementation of Regional Budget Supervision in Makassar City
}

As explained in Peraturan Pemerintah 12/2019 Article 217 paragraph (2), su pervision is carried out in the form of audits, reviews, evaluations, monitoring, technical guidance and other forms of supervision in accordance with statutory provisions.

\section{a. Monev}

Monitoring and evaluation efforts are also referred to as monev. M\&E operations are, in essence, two integrated activities that operate as a single unit but have distinct objectives. Monitoring occurs during the course of the activity to ensure that it is proper, whereas assessment occurs after the activity concludes to determine the activity's final accomplishments. DPRD, as the external supervisor, conducts monitoring and evaluation (monev) meetings during the implementation of APBD supervision.

Along with DPRD, Monev activities are carried out by the Inspectorate as an interna I supervisor. They conduct monitoring by going directly to the field or to the SKPD-SKPD in question to observe and measure activities. If problems are discovered during monitoring, they will evaluate anything that needs to be improved.

\section{b. Audit}

The audit in question is an internal audit, and the audit is being utilized to determine the most effective strategy to address the issues discovered during the audit. The audit process is divided into five stages: 1) scheduling the audit; 2) planning the audit procedure; 3) conducting audits; 4) audit reports; and 5) following up on issues or fixes discovered.

From the results of interviews obtained from informant 3 who is a young auditor at the Makassar City Inspectorate explained that:

\begin{abstract}
"Bahwa Permasalahan yang ada sebelum audit seperti keterlambatan dokumen yang akan di audit dan ada banyak kendala yang ditemukan setelah audit dilakukan. Kendala yang ada kebanyakan bersifat administratif seperti, pertanggungjawabannya yang tidak sesuai dengan ketentuan yang berlaku, ada yang bersifat merugikan keuangan negara/daerah dan jika terbukti pertanggungjawaban yang dilakukan fiktif maka instansi yang melakukannya harus mengembalikan dana tersebut ke dan akas negara/daerah."

"That the problems that existed before the audit such as delays in documents to be audited and there were many obstacles that were found after the audit was carried out. The obstacles that exist are mostly administrative in nature, such as accountability that is not in accordance with applicable regulations, some are detrimental to the state/regional finances and if it is proven that the accountability has been carried out fictitious, the agency that carries it out must return the funds to the state/regional treasury."
\end{abstract}

Based on the results of interviews conducted for this audit, the author finds that the audit process was carried out properly but was not maximized owing to elements who did not follow protocols, such as delays in preparing documents and accountability that did not follow procedures.

\section{c. Review}

Based on the Attachment to the Regulation of the Minister of State Apparatus Empowerment Number PER/05/M.PAN/03/2008 concerning Audit Standards for Government Internal Supervisory Apparatus, a review is a review of evidence of an activity to ensure that the activity has been carried out in accordance with the provisions, standards, plans, or established norms.

The procedure for the review is regulated in the Regulation of the Minister for Empowerment of State Apparatus and Bureaucratic Reform of the Republic of Indonesia Number 53 of 2014 concerning Technical Guidelines for Performance Agreements, Performance Reporting, and Procedures for Reviewing Performance Reports of Government Agencies as follows:

1) The reviewer; Examined by an auditor appointed by the government's internal supervisory apparatus or those established for that purpose. 
2) Timeframe for review implementation; The review stage of performance reporting is a key aspect of performance reporting. The review is conducted concurrently with the adoption of performance management and the creation of Government Agency Performance Reports. The review must be completed prior to being signed by the leadership and presented to the PAN and RB ministers.

3) The review's implementation scope: 1) Techniques for data/information collection. This is done to ensure the data/information supplied in the performance report is reliable and accurate. 2) A brief overview of the SAKIP implementation process. This is done to determine the degree of alignment between strategic planning at the Ministry/Agency/Local Government level and strategic planning at the unit level, particularly in terms of target, performance indicator, program, and activity alignment. 3) Preparation of working papers for review. Examine working papers and contain at the very least the following:

a) Test results on the reliability and accuracy of data or performance information in performance reports;

b) Review of SAKIP implementation activities;

c) The results reviewed and the review steps implemented.

d) The results of the implementation of the review steps and conclusions/review notes.

e) After conducting the review, the reviewer must make a statement that it has been reviewed and the letter is part of the performance report. 5) The review is carried out only on performance reports at the K/L/Pemda level.

4) Review reporting; The review reporting series of activities focuses on accountability for the review's implementation, revealing the procedures carried out, errors or weaknesses discovered, agreed corrective actions, corrective actions taken, and suggestions for improvements that have not been or have not been implemented. The report serves as the foundation for the preparation of the audit. reviewed. a) A review of the performance report for the fiscal year in question has been conducted; $b$ ) The review has been conducted in accordance with the performance report review guidelines; $c$ ) All information contained in the review report is management presentation; $d$ ) The review's purpose is to provide assurance regarding the accuracy, reliability, and validity of performance information contained in performance reports.

\section{Conclusion}

The supervisory system and mechanism carried out by the DPRD has not run optimally and has many shortcomings in the process of monitoring the APBD while the Inspectorate has been running well but has not been maximized due to many administrative errors and mistakes made by several elements. The form of supervision carried out by the Makassar City DPRD is the Monev Meeting and the form of supervision of the Inspectorate includes Audit, Review, Monitoring and Evaluation.

\section{References}

'Amalia, NF (2013). Factors Affecting the Role of DPRD in Regional Financial Supervision. AAJ: Accounting Analysis Journal, 2(3), 295-305.

Fahmil, AM (2008). The Role of the General Principles of Decent Governance in Realizing Clean Government Total Media Creations.

Hamidi, J. (2012). Theory and Law of Regional Regulation Planning. UB Press.

Madura, J. (2001). International Financial Management(1sted.). Erlangga Group.

Mardiasmo. (2002). Public sector accounting. Andi.

Nawawi, B. (2019). The existence of the DPRD's supervisory function on the management of the Parepare City APBD. DIKTUM: Journal of Sharia and Law, 17(2), 314-315.

Pradana, IPYB (2014). Bureaucratic Transparency in APBD Managementin Kupang City. JKAP: Journal of Policy and Public Administration, 18(2), 186-205. 
Syauqi, M., Siregar, H., \& Syaukat, Y. (2017). Strategy to Improve the Efficiency and Effectiveness of the Bogor City Government's Financial Performance in the Management of the Regional Budget. Journal of Regional DevelopmentManagement, 9(1), 2-4.

Yunus, M. (2020). The use of the Makassar City Covid-19 Handling Budgetis not transparent. Suarasulsel.Id. 